\title{
取鍋傾動式自動注湯機における取鍋から流出する液体の落下位置制御*
}

\author{
野田 善之*1, 福嶋 隆輔*2, 寺嶋一彦*3

\section{Falling Position Control of Outflow Liquid from Ladle in Tilting-Ladle Type Automatic Pouring Machine}

\author{
Yoshiyuki NODA*1 ${ }^{*}$, Ryusuke FUKUSHIMA and Kazuhiko TERASHIMA \\ ${ }^{* 1}$ Graduate School of Medicine and Engineering, University of Yamanashi \\ 4-3-11, Takeda, Kofu, Yamanashi, 400-8511, Japan
}

This paper is concerned with an advanced control system for tilting-ladle type automatic pouring machine used in metal-casting industry. In order to pour precisely the liquid outflow from a ladle into a sprue cup of mold, the falling position control system of the outflow liquid is proposed in this paper. In the proposed approach, the mathematical model on the falling position of the outflow liquid is derived from the shape of the ladle and the pouring conditions. The proposed mathematical model is verified by the experiments with the monitoring system to the trajectory of the outflow liquid. The falling position control is constructed by feedforward control using the proposed falling position mathematical model. The effectiveness of the proposed control system is validated through the experiments using the automatic pouring machine with the monitoring system.

Key Words : Falling Position Control, Automatic Pouring Machine, Casting, Modeling, Motion Control, Liquid Trajectory Measurement

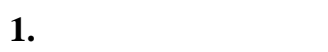

鋳造産業における注湯工程は, 高温の溶湯を鋳型へ注ぐ工程であることから，作業者にとって危険，かつ過酷 な作業環境であり, 現在, 注湯工程の自動化が進められている ${ }^{(1)}$ (4) . 注湯工程では, 安全性と歩留り向上の観点 から, 高精度に鋳型内湯口へ注湯することが求められている. 兴の一方で, 注湯中の溶湯の温度低下による鋳物 品質の低下や生産性向上の観点から, 素早く注湯することも求められている ${ }^{(5)(6)}$.ここで, 自動注湯機における注 湯方式は, 加圧式注湯や, 主に欧州を中心に普及しているストッパーノズル式注湯(7), 図 1 に示す東アジアを中心 に普及している取鍋傾動式注湯がある ${ }^{(1)(6)(8)}$. 取鍋傾動式注湯は , 従来の作業者による手動注湯と同樣の注湯方式 のため, 導入し易い利点をもつ一方で, 他の注湯方式と比較して, 注湯流量や充填量, 流出液体の落下位置の精 度が低く, 兴の高精度化が強く求められている。

光こで近年では, 取鍋傾動式自動注湯機の高速・高精度化に関する制御システムの研究開発が, 数多く報告さ れている . 例えば, 取鍋出湯口を昇降させ , 注湯流量を増大化することで, 素早く湯口内液面レベルを高位置に

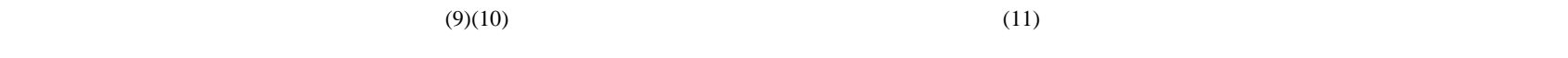
て , 注湯プロセスを線形モデルで表現し , 谷の逆モデルを用いたフィードフォワード制御と $H_{\infty}$ 制御によるフィー ドバック制御を備えた湯口内液面レベル制御 ${ }^{(12)}$ などが挙げられる . また, 円筒形取鍋を備えた自動注湯機に対し て , 注湯プロセスを LPV (線形パラメータ变動) モデルで表現し , 光の逆モデルを用いた注湯制御手法 ${ }^{(13)}$ などが 提案されている.最近の研究成果では, アルミニウム合金の重力鋳造に対して，鋳物品質を悪化させる注湯中の

\footnotetext{
* 原稿受付 2012 年 6 月 4 日

${ }^{* 1}$ 正員, 山梨大学大学院医学工学総合研究部機電情報システム工学系（广400-8511 山梨県甲府市武田 4-3-11）

*2 三菱重工業制御システム技術部（テ851-0392 長崎県長崎市飽の浦 1-1 長崎造船所）

*3 正員, 豊橋技術科学大学大学院工学研究科機械工学系

( ( $441-8580$ 愛知県豊橋市天伯町雲雀ヶ丘 1-1)

E-mail: noday@yamanashi.ac.jp
} 


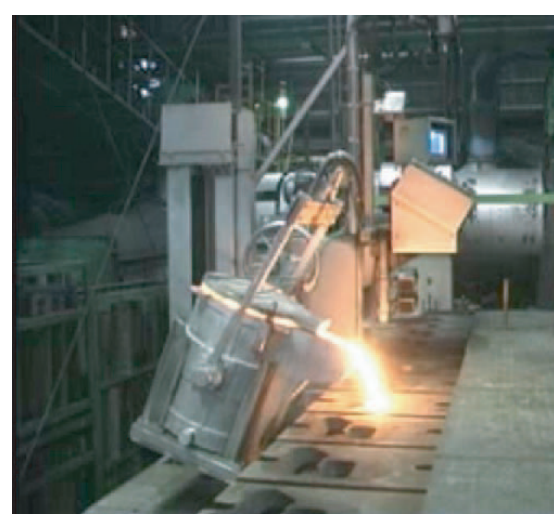

(a) Photo of Tilting-ladle Type Automatic Pouring Machine in Casting Plant

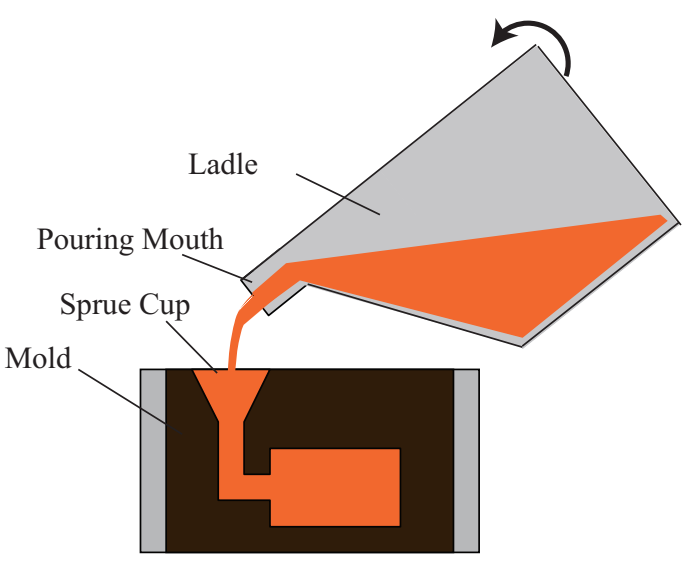

(b) Tilting-ladle Type Pouring

Fig. 1 Automatic Pouring Machine in Practical Use

空気巻き込みを低減させ，かつ注湯時間を短縮する注湯動作を CFD(Computational Fluid Dynamics) を用いて最適 化する研究 ${ }^{(14)(15)}$ などか報告されている.著者らは流体力学に基づいて注湯プロセスの数理モデルを導出し, 弚の 逆モデルによるフィードフォワード型注湯流量制御を提案している ${ }^{(16)(23)}$. また , 提案した注湯プロセスの数理モ デルを用いて，目標充填量へ高精度に注湯するように，シーケンス制御による充填量制御の制御パラメータを最 適化する充填量制御設計法を提案している ${ }^{(18)}$. 上述に示すように従来研究の多くが，注湯流量制御や充填量制御， 湯口内液面レベル制御に関する研究である。しかしながら，取鍋から流出した液体を鋳型内湯口へ高精度に注入 する流出液体の落下位置制御も自動注湯機の高精度化には強く求められている ${ }^{(19)}$. この落下位置制御は, 注湯液 体が湯口から外れるのを回避するだけではなく, 落下位置の高精度化によっで湯口の小径化を可能にし, 歩留りを 向上させることが期待できる . 後述に示す注湯実験において, 注湯流量 $0.5 \times 10^{-3}\left[\mathrm{~m}^{3} / \mathrm{s}\right]$ で, 出湯口と湯口の高低 差が $0.2[\mathrm{~m}]$ の場合, 取鍋から流出した液体の落下位置が約 $0.09[\mathrm{~m}]$ となり, 注湯流量の変動で落下位置が更にば らつく. 現在の鋳造方案ではこれらの注湯落下位置のばらつきを考慮して湯口径が決められており，落下位置のば らつきを抑制することで, 湯口の小径化が実現する .

乥こで, 本研究では取鍋傾動式自動注湯機に対して, 取鍋から流出する液体が所望の位置へ高精度に注湯され る落下位置制御システムを開発する.著者らが提案している注湯プロセスの数理モデルに, 流出液体の放物運動 を加えた落下軌跡モデルを提案する．乥して，カメラシステムによる流出液体の落下位置計測システムを構築し， 落下軌跡モデルの実験検証を行う . 提案された流出液体の落下軌跡モデルを基に, 所望の位置へ高精度に注湯す るように取鍋を前後移動させる落下位置制御システムを提案する．最後に，カメラシステムによる落下位置計測 システムを備えた自動注湯機を用いて，提案する落下位置制御システムの有用性を検証する．

\section{2. 取鍋傾動式自動注湯機}

本研究で用いる取鍋傾動式自動注湯機の概要を図 2(a) に示す．取鍋は Y 軸（前後方向），Z軸（上下方向）光

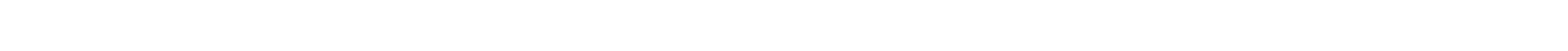

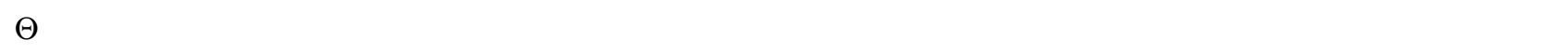
置, 傾動角度を計測することができる . 取鍋内の液体重量は, 取鍋支持部に内蔵されているロードセルにより計 測される．サーボモータシステムは, DSP(Digital Signal Processor) から光れぞれのモータドライバへ速度指令信

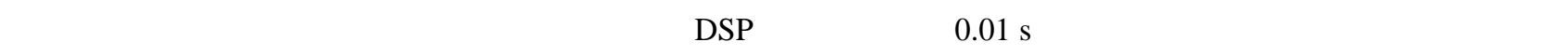
い制御周期である ${ }^{(18)}$. 実際の鋳造工場で用いられる自動注湯機の多くは, 図 2(a) に示す自動注湯機と同樣の構成 を有する。ここで, 本研究では安全性のために, 注湯実験に用いる対象液体を水とし, 図 2(b) に示す形状を有す るアクリル製取鍋を用いる.水 $(293.2 \mathrm{~K})$ の動粘性係数は $1.0 \times 10^{-6} \mathrm{~m}^{2} / \mathrm{s}$ であり，溶湯 $(1400.2 \mathrm{~K})$ の動粘性係数 は $1.237 \times 10^{-6} \mathrm{~m}^{2} / \mathrm{s}$ と近い值にあることから，レイノルズの相似則より両者の挙動はほぼ同樣であると考えられる (20). また，実際の注湯工程において，水と溶湯の流れ挙動が異なった場合でも，本研究で提案する注湯制御系設 


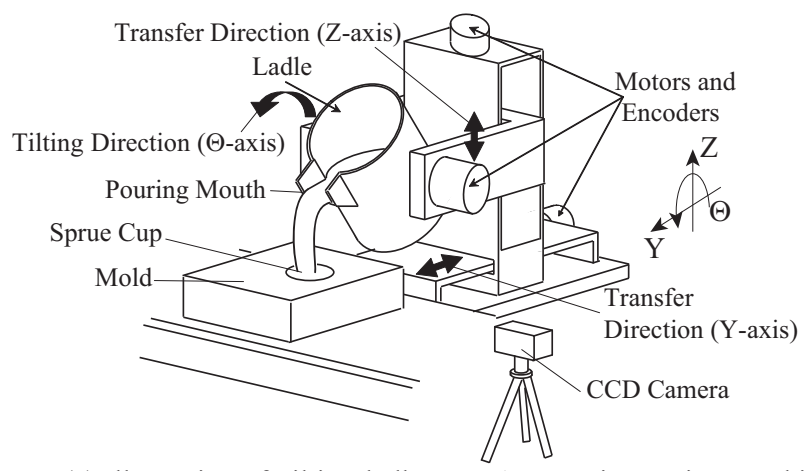

(a) Illustration of Tilting-ladle Type Automatic Pouring Machine

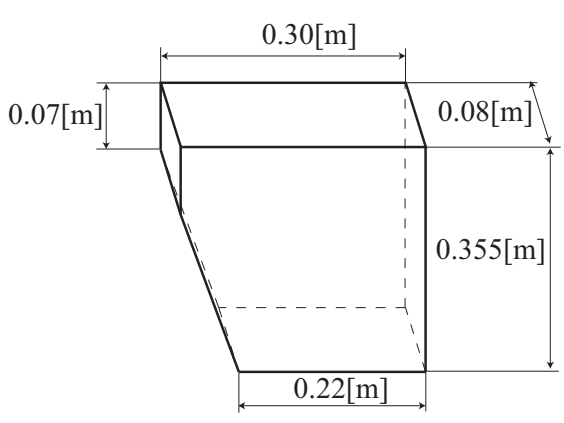

(b) Geometry of Ladle

Fig. 2 Illustration of Tilting-ladle Type Automatic Pouring Machine in This Study
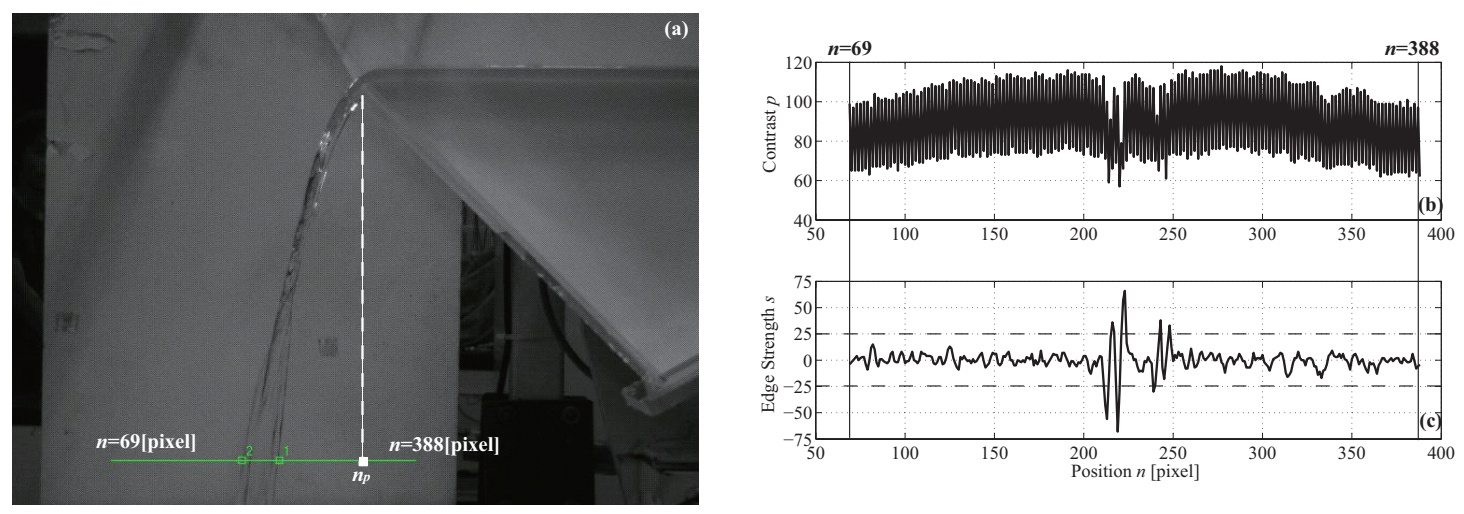

Fig. 3 Picture of Outflow Liquid by Camera System and Detection Method of Falling Position

計法における液体特性に関するモデルパラメータ (流量係数) を同定することで, 実際の鋳造工場で用いられる 自動注湯機でも同樣の結果が得られるものと考える．

本研究では, 取鍋からの流出液体落下位置を計測するために, 自動注湯機の側方にカメラシステムを設置する .

\section{$2 \cdot 1$ 流出液体の落下位置計測}

図 3(a) は , カメラにより撮影された取鍋からの流出液体を示す . カメラシステムは , フレームレート $180.16 \mathrm{fps}$, 1 フレーム当たり $640 \times 494$ pixel のグレイスケールで流出液体を撮影している. 乥して, 得られた画像データから 流出液体の落下位置計測を行う水平方向の 1 行を抽出する . 図 3(b) には, 抽出行のコントラスト (256 階調) を示 す .この抽出行のコントラストに対して, 平滑化フィルタでノイズを低減し，流出液体の端点を強調するために， つぎの処理が実行される ${ }^{(21)}$.

$$
s(n)=\frac{1}{2} \sum_{i=0}^{2} p(n+i-2) c(i), c=(-1,0,1)
$$

ここで,$s$ はエッジ強度であり,$p$ はコントラスト,$c$ はエッジ強調のための微分オペレータである.$n$ はピクセル 番号を示す. 式(1)により得られたエッジ強度を図 3(c) に示す. 光して, 図 3(c) に示されるエッジ強度に対して， 次式により流出液体落下位置を計測する。

$$
f_{p}=\left\{n_{p}-\frac{\max (m)+\min (m)}{2}\right\} \kappa,\left(m=\arg |s(n)|>s_{t h}\right)
$$

ここで, $n_{p}$ は, 図 3(a) に示すように, 取鍋出湯口先端の水平方向ピクセル番号であり， $\kappa(\mathrm{m} / \mathrm{pixel})$ は単位ピクセ ル当たりの長さを示す . 図 $3(\mathrm{a}) て ゙ は ， \kappa=0.8 \times 10^{-3} \mathrm{~m} / \mathrm{pixel}$ が与えられている . $s_{t h}$ はエッジを判別する閯值である . 本研究では，図 3(c) の破線で示されるように, $s_{t h}=25$ が与えられている. 乥して，式 (2) の $\max (m)$ と $\min (m)$ は， 流出液体の端点を示している . 図 3 では上述の処理によって, 流出液体の落下位置 $f_{p}$ は $0.057 \mathrm{~m}$ となる . 各フレー ムに対して上述の処理が実行され，カメラによる流出液体撮影から落下位置計測までの処理が $0.02 \mathrm{~s}$ で害行され ている. 


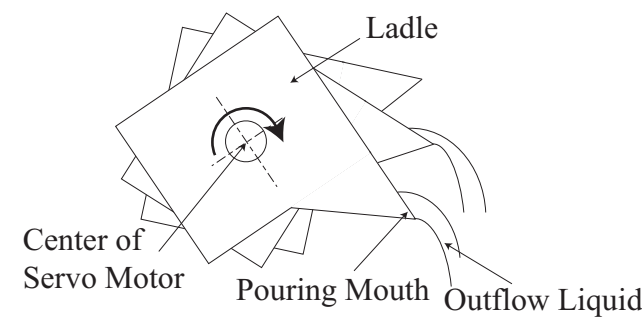

(a) Tilting Ladle without Syncronous Control

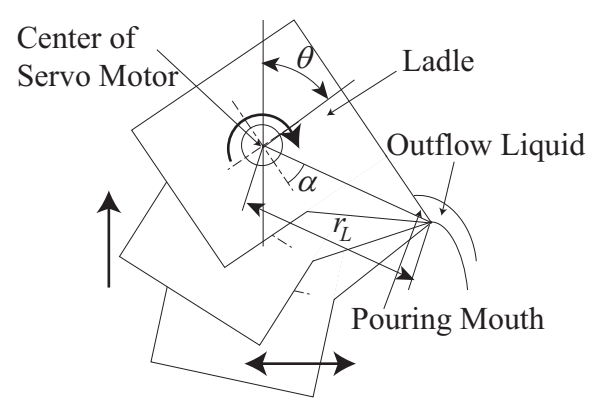

(b) Tilting Ladle with Syncronous Control

Fig. 4 Synchronous Control of Tilting and Transferring of Ladle

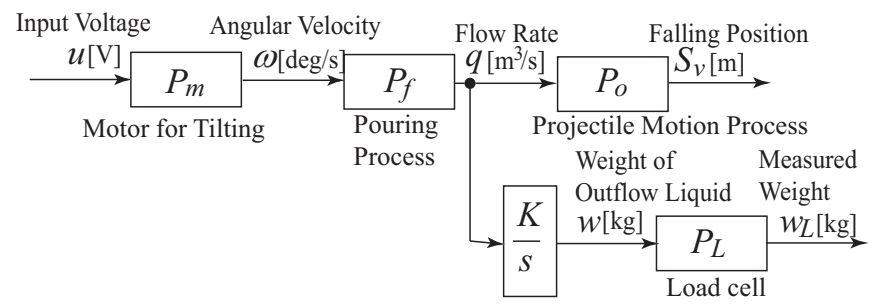

Fig. 5 Process Diagram of Tilting-ladle Type Automatic Pouring Machine

2.2 出湯口先端を中心に取鍋を回転させる取鍋傾動・搬送同期制御 ${ }^{(22)}$

取鍋傾動用モータは図 4(a)に示すように取鍋重心付近に取付けられているため，モータ軸中心で取鍋を傾動さ せると出湯口が円弧軌道を描く.これにより, 取鍋から流出する液体の落下位置が安定せず, 正確な位置へ注湯す ることが困難となる，乥こで, 図 4(b) に示すように, 取鍋傾動に連動して, 取鍋を上下, 前後動させ , 出湯口先端 を回転中心にする . 出湯口先端を回転中心にするための取鍋の Y 軸 , Z 軸光れ光れの移動量 $y_{s}, z_{s}$ を次式に示す．

$$
\begin{gathered}
y_{s}=r_{L} \cos \alpha-r_{L} \cos (\alpha-\theta) \\
z_{s}=r_{L} \sin \alpha-r_{L} \sin (\alpha-\theta)
\end{gathered}
$$

ここで, $r_{L}(\mathrm{~m})$ は, モータ軸中心から出湯口先端までの長さであり， $\alpha(\mathrm{rad})$ は取鍋が直立状態におけるモータ軸中 心と出湯口先端を結ぶ直線と水平線のなす角度である. $\theta(\mathrm{rad})$ は取鍋の傾動角度である.この取鍋傾動・搬送同期 制御により，取鍋出湯口先端が取鍋傾動の回転中心となり，流出する液体の落下位置のばらつきを抑えることがで きる .

\section{3. 取鍋傾動式自動注湯機の数理モデル}

本章では, 取鍋傾動式自動注湯機の数理モデルを導出する.自動注湯機は図 5 に示すように，モータへ指令電 圧が与えられ，取鍋が傾動し，取鍋内液体が流出する，光して，自動注湯機に内蔵されたロードセルにより，取鍋 から流出した液体の流出重量か計測される．また，取鍋から流出した液体は，放物運動プロセスを経て，鋳型内 湯口へ注がれる．モータシステム, 注湯プロセス, ロードセル, および流出液体の放物運動プロセスに対する光

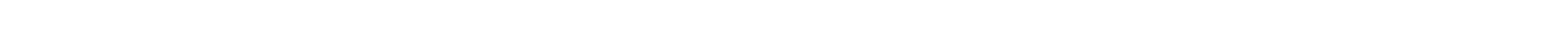
出重量までの数理モデルの導出の詳細については, 文献 ${ }^{(16)(23)}$ を参照されたい .

\section{$3 \cdot 1$ モータモデル(16)}

取鍋傾動に対するサーボモータシステムは, 角速度制御を内蔵しており, 所望の取鍋傾動角速度を実現する . 本 研究では, モータへの指令電圧 $u(\mathrm{~V})$ から取鍋傾動角度 $\theta$ までのモータモデルを次のように表現する．

$$
\left[\begin{array}{c}
\dot{\omega}(t) \\
\dot{\theta}(t)
\end{array}\right]=\left[\begin{array}{cc}
-\frac{1}{T_{m t}} & 0 \\
1 & 0
\end{array}\right]\left[\begin{array}{c}
\omega(t) \\
\theta(t)
\end{array}\right]+\left[\begin{array}{c}
\frac{K_{m t}}{T_{m t}} \\
0
\end{array}\right] u(t)
$$




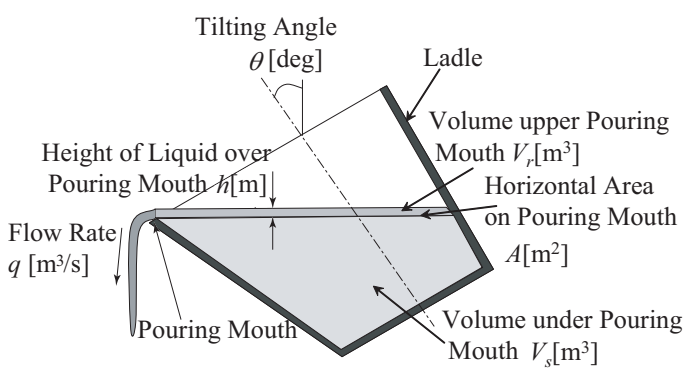

(a) Parameters in Pouring Process

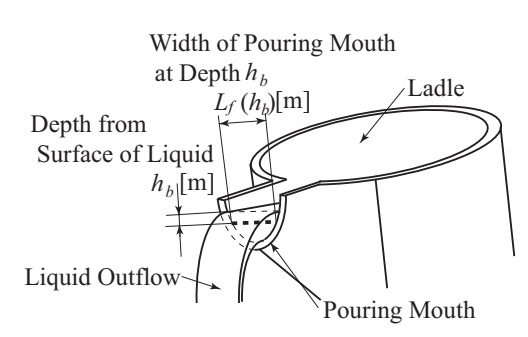

(b) Parameters on Pouring Mouth

Fig. 6 Parameters of Pouring Process

ここで, $\omega(\mathrm{rad} / \mathrm{s})$ は取鍋傾動角速度である.$T_{m t}(\mathrm{~s})$ はモータの時定数， $K_{m t}(\mathrm{rad} / \mathrm{s} / \mathrm{V})$ はゲイン定数を示す . 時定数と ゲイン定数は, 実験結果とシミュレーション結果のフィッティングにより求める.

\section{$3 \cdot 2$ 注湯プロセスモデル ${ }^{(16)}$}

図 6(a) は, 取鍋の傾動角度 $\theta$ における注湯状態を示している. 取鍋が角速度 $\omega$ で傾動し, 出湯口より上方の液 体が流量 $q\left(\mathrm{~m}^{3} / \mathrm{s}\right)$ で流出する .このときの物質収支式は次式で示される.

$$
\dot{V}_{r}(t)=-q(t)-\frac{\partial V_{s}(\theta(t))}{\partial \theta(t)} \omega(t)
$$

ここで, $V_{r}\left(\mathrm{~m}^{3}\right)$ は取鍋の出湯口より上部の液体体積を示し， $V_{s}\left(\mathrm{~m}^{3}\right)$ は出湯口より下部の液体体積を示す．弚して， 出湯口より上部の液体高さ $h(\mathrm{~m})$ は式 (7) で近似することができる.

$$
h(t) \approx \frac{V_{r}(t)}{A(\theta(t))}
$$

$A\left(\mathrm{~m}^{2}\right)$ は, 出湯口下端位置に水平な取鍋内液体の面積である . 出湯口上部の流れに対して, 全ての流線が十分に上 流の取鍋内液面から開始すると仮定すると, ベルヌーイの定理より, 出湯口より上部液体の高さと取鍋流出流量 の関係は次式となる .

$$
q(t)=c \int_{0}^{h(t)}\left(L_{f}\left(h_{b}\right) \sqrt{2 g h_{b}}\right) d h_{b}, \quad(0<c<1)
$$

ここで, $L_{f}(\mathrm{~m})$ は図 6(b) に示すように取鍋液体上面からの深さ $h_{b}(\mathrm{~m})$ における出湯口の幅である . また,$c$ は流量 係数であり, $g\left(\mathrm{~m} / \mathrm{s}^{2}\right)$ は重力加速度である . 流量係数 $c$ は, 実験により得られる取鍋から流出した流出重量とモデ ルにより得られる流出重量のフィッティングにより同定される.式 (8)において, 出湯口か矩形の場合は, 出湯口 より上部液体の高さと取鍋流出流量の関係は次式となる .

$$
q(t)=\frac{2}{3} c L_{f} \sqrt{2 g h(t)^{3}}, \quad(0<c<1)
$$

そして, 取鍋から流出した液体の流出重量 $w(\mathrm{~kg})$ と流量 $q\left(\mathrm{~m}^{3} / \mathrm{s}\right)$ の関係は次のように示される.

$$
\dot{w}(t)=\rho q(t)
$$

ここで, $\rho\left(\mathrm{kg} / \mathrm{m}^{3}\right)$ は液体の密度である．

\section{$3 \cdot 3$ ロードセルモデル ${ }^{(16)}$}

取鍋から流出した液体の流出重量は自動注湯機に内蔵されているロードセルにより計測される．ロードセルの 動特性は，次に示す 1 次遅れ系で表現される.

$$
\dot{w}_{L}(t)=-\frac{1}{T_{L}} w_{L}(t)+\frac{1}{T_{L}} w(t),
$$

ここで, $w$ は取鍋から流出する液体の流出重量であり， $w_{L}(\mathrm{~kg})$ はロードセルによって計測される流出重量である. $T_{L}(\mathrm{~s})$ はロードセルの時定数を示す . ロードセルの時定数は, 既知重量のおもりを空の取鍋容器に載せた際のステッ プ応答から同定する . 


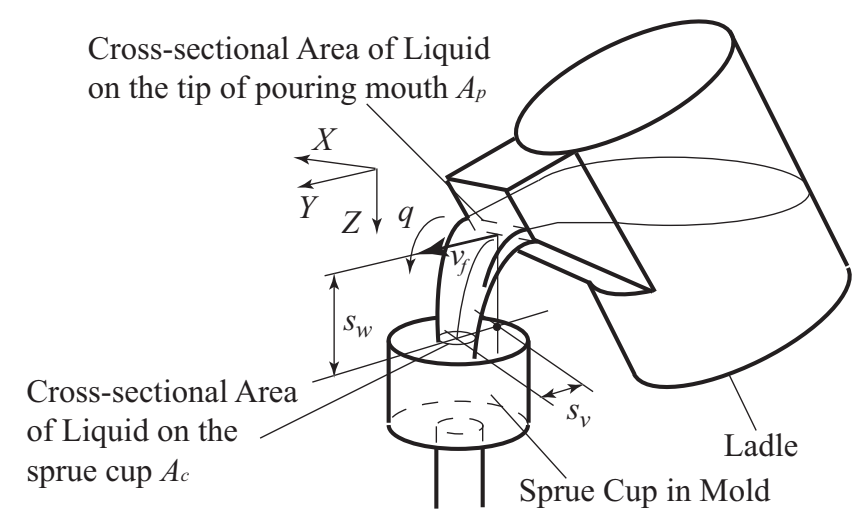

Fig. 7 Falling Position Process of Outflow Liquid from Ladle

\section{4 流出液体の放物運動モデル}

図 5 における $P_{o}$ は取鍋から流出した液体の放物運動プロセスを示す. 流出液体の放物運動の概要を図 7 に示す. 図 7 において, $A_{p}\left(\mathrm{~m}^{2}\right)$ は出湯口先端における流出液体の垂直断面積を示し, $v_{f}(\mathrm{~m} / \mathrm{s})$ は出湯口先端での流出液体 の平均流速を示す . 平均流速 $v_{f}$ と注湯流量の関係は次式のように示される .

$$
v_{f}(h(t))=\frac{q(h(t))}{A_{p}(h(t))}
$$

ここで , 出湯口が矩形の場合は, 平均流速が次式となる .

$$
v_{f}(h(t))=\frac{q(h(t))}{L_{f} h(t)}=\frac{2}{3} c \sqrt{2 g h(t)}
$$

乥して, 大気中へ放出された液体の挙動は質点系の放物運動と同樣の軌跡を描くことが流体力学や水理学で知 られている(24)(25) .また, 著者らの過去の研究において, 取鍋から流出した液体の落下軌跡が, 出湯口流速を初速 度とした放物運動軌跡と類似していることが確認されている ${ }^{(23)}$.このことから，出湯口先端を原点とした流出液 体の微小区間における水平方向位置 $s_{v}(\mathrm{~m})$ および垂直方向位置 $s_{w}(\mathrm{~m})$ は次のように示される.

$$
\begin{gathered}
s_{v}(t)=v_{f}\left(t_{0}\right)\left(t-t_{0}\right), \\
s_{w}(t)=\frac{1}{2} g\left(t-t_{0}\right)^{2}
\end{gathered}
$$

ここで, $t_{0}(\mathrm{~s})$ は取鍋から流出する液体において, 微小区間の液体が出湯口先端を通過した時刻を示す，光して，式 (14) を式 (15) に代入することで, 出湯口先端を原点とした垂直方向位置 $s_{w}$ における流出液体の水平方向位置 $s_{v}$ の 関係が次式となる .

$$
s_{v}(t)=v_{f}\left(t_{0}\right) \sqrt{\frac{2 s_{w}(t)}{g}}
$$

\section{$3 \cdot 5$ モデル検証実験}

注湯実験により，前節に示す自動注湯機の数理モデルの検証を行う .ここで, 注湯プロセスモデルにおけるモデ ルパラメータ $A, V_{s}$ およびこれらの傾動角度による微分 $\partial A / \partial \theta, \partial V_{s} / \partial \theta$ を図 8 に示す . これらのパラメータは， 図 2(b) に示す取鍋形状より得られる . また，モータモデルのパラメータ $T_{m t}, K_{m t}$, 注湯プロセスモデルの流量係 数 $c$, 液体密度 (水) $\rho$ およびロードセルモデルの時定数 $T_{L}$ を表 1 に示す.

検証実験では，注湯流量と取鍋から流出する液体の落下位置の関係を明確にするために，モータモデルおよび 注湯プロセスモデルの逆モデルによるフィードフォワード流量制御を自動注湯機に実装し, 定常流量での流出液 体の落下位置をカメラシステムにより確認する．

ここで, 角速度制御を用いたモータシステムの応答性は注湯プロセスの応答性より十分に速いことから，指令 電圧から取鍋傾動角速度までのモータモデルを次式のように示す．

$$
\omega(t)=K_{m t} u(t)
$$



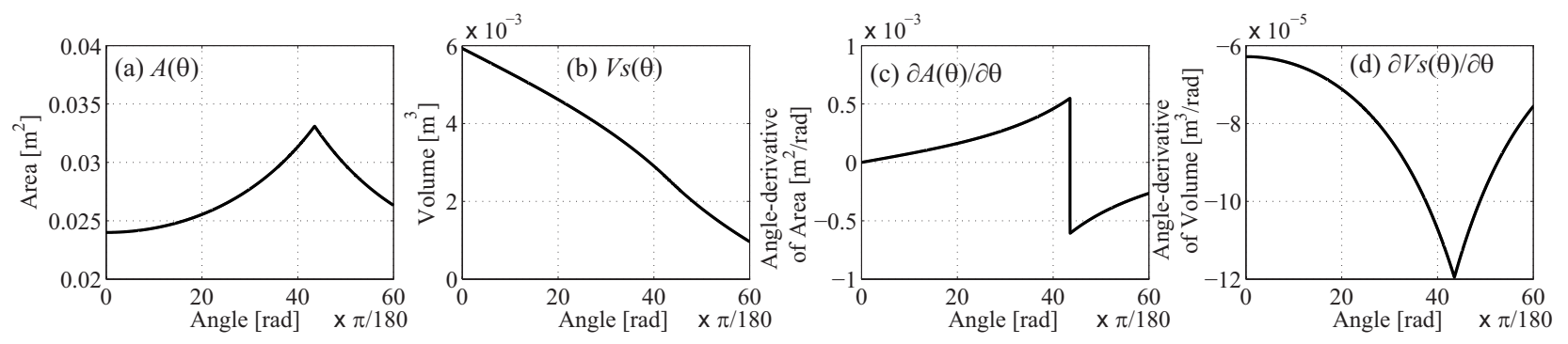

Fig. 8 Model Parameters Depending on Tilting Angle of Ladle

Table 1 Model Parameters

\begin{tabular}{l||c}
\hline Time Constant of Motor, $T_{m t}[\mathrm{~s}]$ & $0.60 \times 10^{-2}$ \\
\hline Gain of Motor $K_{m t}[\mathrm{rad} / \mathrm{s} / \mathrm{V}]$ & 0.86 \\
\hline Flow Rate Coefficient of Pouring, $c[-]$ & 0.90 \\
\hline Density of Liquid (Water), $\rho\left[\mathrm{kg} / \mathrm{m}^{3}\right]$ & $1.00 \times 10^{3}$ \\
\hline Time Constant of Load Cell, $T_{L}[\mathrm{~s}]$ & $0.50 \times 10^{-1}$ \\
\hline
\end{tabular}

そして , 式 (17) に示すモータモデルと式 (6) および式 (7) に示す注湯プロセスモデルの逆モデルより得られる傾動 用モータへの指令電圧は次式となる .

$$
\begin{gathered}
u(t)=-\frac{A\left(\theta_{\text {ref }}(t)\right) \dot{h}_{r e f}(t)+q\left(h_{r e f}(t)\right)}{\left.K_{m t} \frac{\partial V_{s}(\theta)}{\partial \theta}\right|_{\theta=\theta_{r e f}(t)}+\left.\frac{\partial A(\theta)}{\partial \theta}\right|_{\theta=\theta_{r e f}(t)} h_{r e f}(t)}, \\
\theta_{r e f}(t)=K_{m t} \int_{0}^{t} u(\tau) d \tau+\theta_{0}
\end{gathered}
$$

$h_{r e f}(\mathrm{~m})$ は , 出湯口より上部の液体高さの目標軌道であり， $\theta_{0}(\mathrm{rad})$ は取鍋の初期傾動角度である.$\theta_{r e f}(\mathrm{rad})$ は傾動 角度の目標軌道である。

そとて, 注湯流量と出湯口より上部の液体高さの関係は, 式 (8) に示す $L_{f}\left(h_{b}\right) \sqrt{2 g h_{b}}$ が正数であるため, 式 (8) は増加関数である.このことから, 兴の逆関数も一意となる. 光こで, 式 (8)の逆関数を用いることで, 目標注湯 流量 $q_{r e f}\left(\mathrm{~m}^{3} / \mathrm{s}\right)$ に対する出湯口より上部の液体高さの目標軌道 $h_{r e f}$ が得られる . 出湯口が矩形の場合は, 式 (9)の 逆関数が次のように解析的に得られる。

$$
h_{r e f}(t)=f^{-1}\left(q_{r e f}(t)\right)=\sqrt[3]{\frac{9 q_{r e f}(t)^{2}}{8 c^{2} L_{f}^{2} g}}
$$

式 (20) に 1 階微分可能な目標流量の軌道 $q_{r e f}(t)$ を与えて, 得られた出湯口より上部の液体高さの目標軌道 $h_{r e f}(t)$ と初期傾動角度 $\theta_{0}$ を式 (18) と（19) に与えることで, 目標注湯流量を実現する傾動用モータへの指令電圧 $u$ が得 られる.

上述の流量制御を用いた注湯実験の結果を図 9 に示す．図 9 において，(a) は傾動モータへの指令電圧であり， (b) は取鍋の傾動角度である . (c) は注湯流量を示し, (d) はロードセルによって計測される取鍋から流出する液体 の流出重量である、実線は実験結果を示し，破線は前節までに示した自動注湯機の数理モデルによるシミュレー ション結果である. (e) $(\mathrm{g})$ は, 出湯口から下方へ $0.10,0.15,0.20 \mathrm{~m}$ の位置における流出液体の水平方向落下位 置を兴れ光れ示す . (e)〜 (g) においては, 黑丸は実験による落下位置であり，破線は数理モデルによって得られた 落下位置を示す . 図 9(b)において, シミュレーションによる取鍋傾動角度と実験による傾動角度が精度良く追従し ている . また, 実験での注湯流量計測は困難であることから, 本研究では図 9(c) に示すように, シミュレーション による注湯流量のみを示している、落下軌跡を精度良く計測するために, 逆モデルによる流量制御を用いて，2.00s 〜 5.00s の間を定常流量 $0.5 \times 10^{-3} \mathrm{~m}^{3} / \mathrm{s}$ となるようにしており，図 9(c) ではシミュレーション結果のみの掲載では あるが流量が定常していることを示している．として，図 9(d) に示す流出液体重量では, 実験結果において 1.0(s) 付近および $6.5(\mathrm{~s})$ 付近においてインパルス状の応答か現れている.これは, 取鍋重心が上下方向に加速した際に生 じるロードセルの応答であり，実際に流出した液体重量ではない．したがって，(d) における $2.0 \mathrm{~s} 〜 6.00 \mathrm{~s}$ 間が示す 

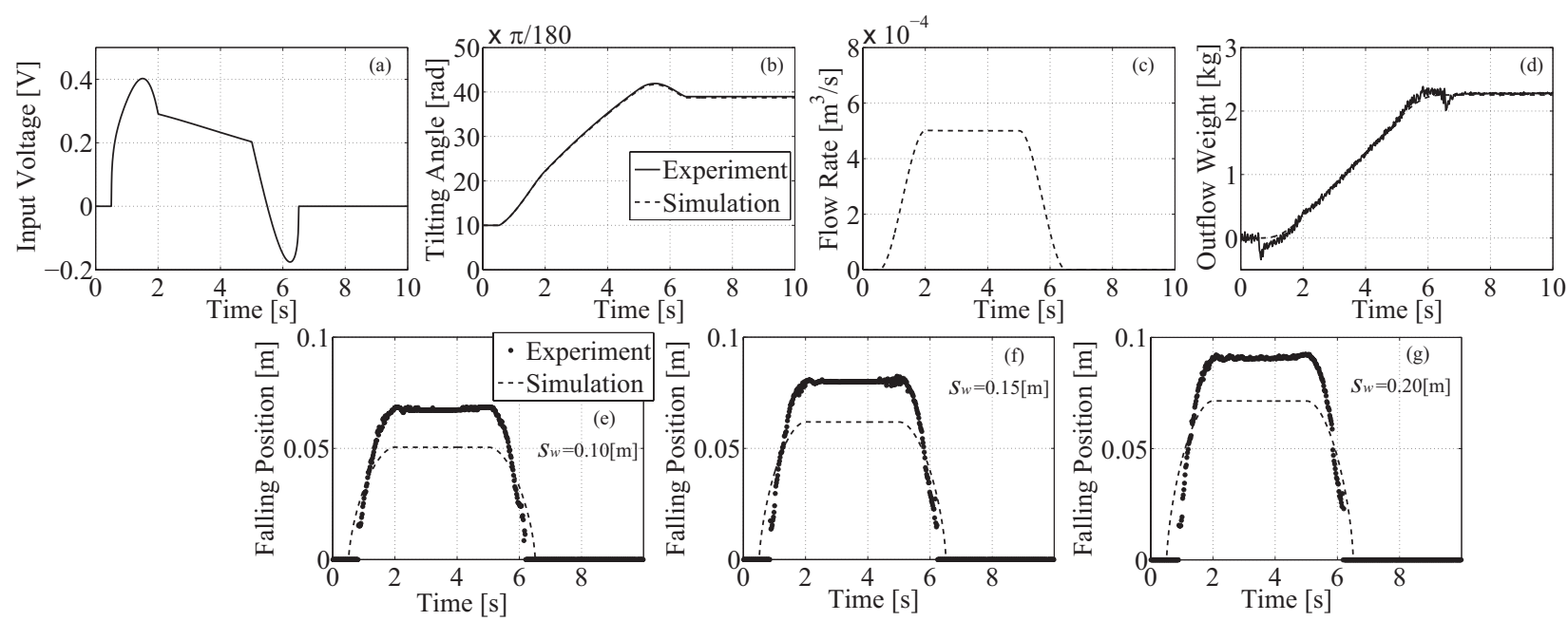

Fig. 9 Experimental Results by Automatic Pouring Machine

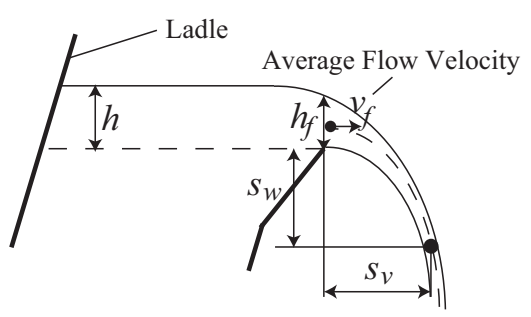

Fig. 10 Flow Condition in Ladle

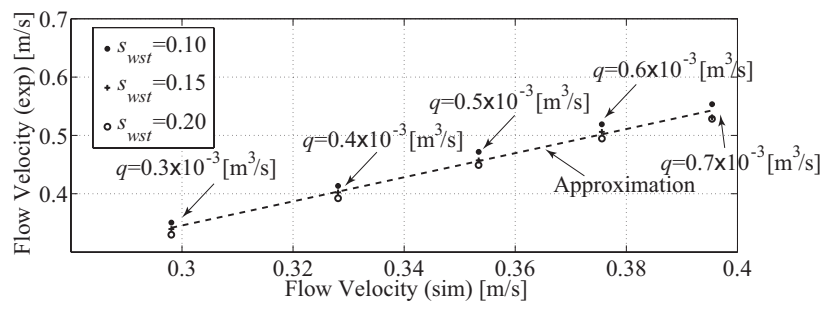

Fig. 11 Comparison of Average Flow Velocities on Pouring Mouth by Simulations and Experiments

ように, シミュレーションによる流出重量が実験による流出重量を精度良く表現していることが確認でき, 数理 モデルの注湯流量と実験による注湯流量は同等であるといえる .

一方で, 図 9(e)〜 (g) では, 実験による落下位置よりも数理モデルによる落下位置の方が小さいことが確認でき る.これは, 图 10 に示すように, 液体か取鍋から大気へ放出される際の流線の変化に伴い, 流線に直交する液体 断面が収縮し，流速が速くなったことが要因として挙げられる ${ }^{(25)}$.

そこで，定常注湯流量を $0.3,0.4,0.5,0.6,0.7 \times 10^{-3} \mathrm{~m}^{3} / \mathrm{s}$ と変化させた実験での取鍋出湯時の流速とシミュ レーションによる流速を比較する . シミュレーションによる流速は式 (12) より得られる . 実験における取鍋出湯 口先端での流速 $v_{f s t}(\mathrm{~m} / \mathrm{s})$ は, 実験により得られた定常流量時の流出液体の落下軌跡 $\left(s_{v s t}, s_{w s t}\right)(\mathrm{m})$ を次式に代入す ることにより得られる．

$$
v_{f s t}=s_{v s t} \sqrt{\frac{g}{2 s_{w s t}}}
$$

ここで, 式 (21) は式 (16) から導出できる . また, 定常流量時の流出液体の落下軌跡 $\left(s_{v s t}, s_{w s t}\right)$ は, 実験より得られ た定常流量時の落下軌跡の平均值としている . シミュレーションと実験による出湯口先端での平均流速の比較結 果を図 11 に示す. 図 11 において, 横軸はシミュレーションによる出湯口先端の平均流速であり, 縦軸は実験に より得られた流出液体の落下軌跡に対して式 (21) を用いて求めた出湯口先端の平均流速である . 黑丸は落下軌跡 

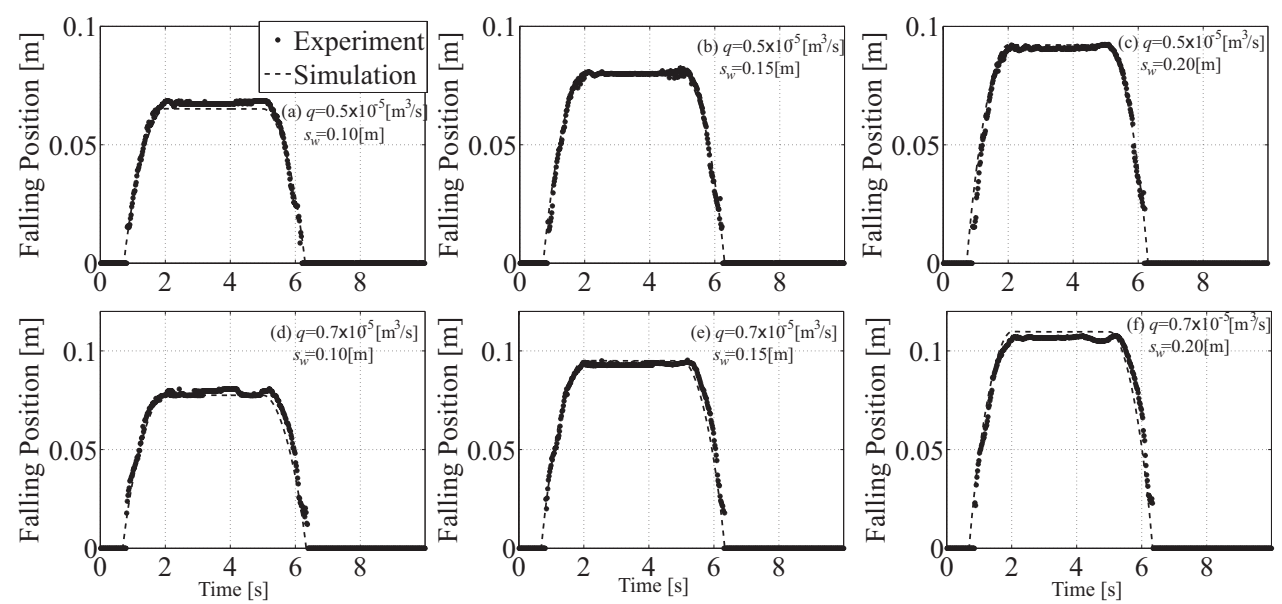

Fig. 12 Falling Positions of Outflow Liquid on Simulations and Experiments

の垂直方向位置 $s_{w s t}=0.10 \mathrm{~m}$ における水平方向位置 $s_{v s t}$ を式 (21) に代入して得られた平均流速であり，薄色の+印

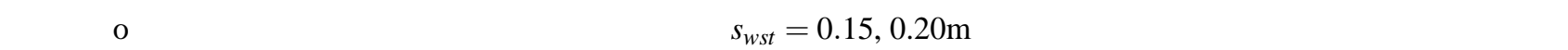
流速である . 図 11 からも確認できるように, 異なる流量においても実験による平均流速の方がシミュレーション よりも速い．また，流量 $q$ の増加に伴い，シミュレーションと実験による平均流速の関係が線形的に増加してい ることが確認できる. そして, 落下軌跡の垂直方向位置 $s_{w s t}$ の増加に伴い, 僅かに実験による平均流速の減速が 確認できる .これは，流出液体か落下中に空気抵抗により僅かに減速したものと考えられる .この結果において， 同一定常流量における落下軌跡に対して，3つの異なる垂直方向位置 $s_{w s t}=0.10,0.15,0.20 \mathrm{~m}$ と光れ光れに対応 する水平方向位置 $s_{v s t}$ を, 式 (21) に与えて得られた出湯口での平均流速は同等であることが確認できる . これ は, 大気中に放出された流出液体が放物運動で表現できていることを示している．乥こで，本研究では落下中の 流出液体の減速は微小として考慮せず, シミュレーションと実験による平均流速の関係を次式のように近似する。

$$
v_{f r}=\beta_{1} v_{f}+\beta_{0}, \quad\left(v_{f r} \geq 0\right)
$$

この近似式に, 数理モデルによって得られた平均流速 $v_{f}(\mathrm{~m} / \mathrm{s})$ を代入することで, 出湯口先端での液体断面収縮を 考慮した平均流速 $v_{f r}(\mathrm{~m} / \mathrm{s})$ が得られる. 本実験により得られた近似式の係数 $\beta_{1}$ および $\beta_{0}$ は，光れ光れ $2.067 ， お$ よび-0.275であり，近似線を図 11 の破線に示す.

式 (22) を自動注湯機の数理モデルに導入して得られた水平方向落下位置を図 12 に示す. 図 12 において, (a) 〜 (c) は, 図 9 に示した定常流量 $0.50 \times 10^{-3} \mathrm{~m}^{3} / \mathrm{s}$ での注湯動作による水平方向落下位置であり, (a), (b), (c) は光 れ出湯口先端から下方へ $0.10,0.15,0.20 \mathrm{~m}$ の水平面における流出液体の落下位置である . (d) (f) は定常流量 $0.70 \times 10^{-3} \mathrm{~m}^{3} / \mathrm{s}$ での注湯動作による水平方向落下位置であり，(d)，(e)，(f) は光れ光れ出湯口先端から下方へ 0.10 , $0.15,0.20 \mathrm{~m}$ の水平面における流出液体の落下位置である . 黑丸は実験結果であり，破線は出湯口先端での液体断 面収縮の影響を考慮した数理モデルによるシミュレーション結果である .これらの結果より, 出湯口先端での液体 断面収縮の影響を考慮し, 落下中の液体は放物運動とした自動注湯機の数理モデルを用いることで, 高精度に流 出液体の落下位置を表現することができる．

\section{4. 流出液体の落下位置制御}

前章で提案された自動注湯機の数理モデルを基に，流出液体の落下位置制御を構築する . 提案する落下位置制 御システムを図 13 に示す，落下位置制御システムは，注湯流量に基づいて設計される．したがって，式(18)およ び (19)に示す注湯プロセスの逆モデルによるフィードフォワード型注湯流量制御を構築し, 実際の注湯流量 $q$ が 目標注湯流量 $q_{r e f}$ に精度良く追従しているという仮定の下で落下位置制御か構築される。

図 13 におけるブロック $E_{f}$ では, 目標注湯流量 $q_{r e f}$ に対して, 式 (12)および (22)を用いて出湯口先端での平均 流速 $\bar{v}_{f r}(\mathrm{~m} / \mathrm{s})$ が推定される. 乥して，ブロック $E_{o}$ では，推定された平均流速 $\bar{v}_{f r}$ と落下位置制御を所望する出湯 


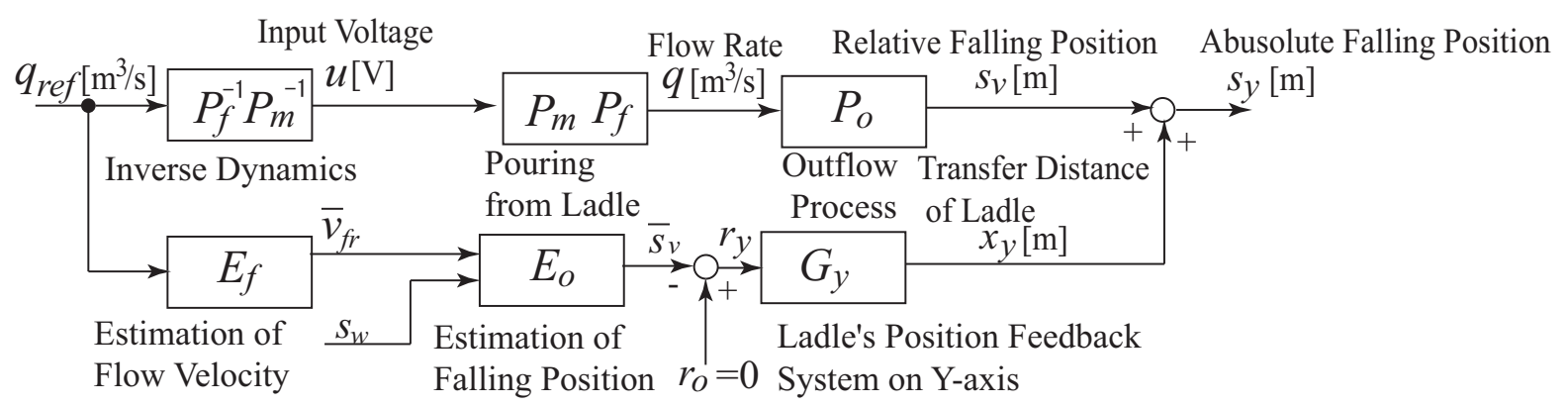

Fig. 13 Block Diagram of Falling Position Control System of Liquid Outflow from Ladle
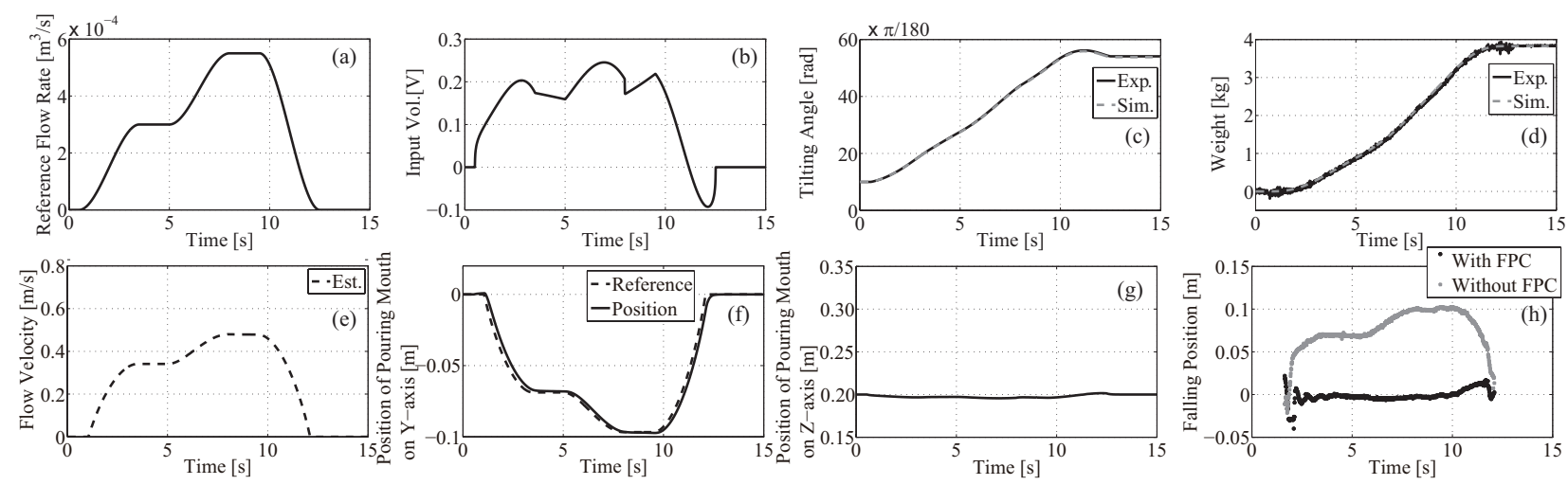

Fig. 14 Experimental Results with Varying Pouring Flow Rate

口先端からの垂直方向位置 $s_{w}$ を式 (16) に与えることで, 流出液体の水平方向落下位置 $\bar{s}_{v}(\mathrm{~m})$ が推定される . 推定 された落下位置 $\bar{s}_{v}$ の符号を反転させて, 取鍋の水平方向搬送のための位置制御システムに目標值として与えるこ とで, 取鍋が移動し, 取鍋からの流出液体が所望の位置へ注湯される . 本研究では, 鋳型内湯口の中心を自動注 湯機の全体座標系の原点としており, 全体座標系における流出液体落下位置が原点 $\left(s_{y}=0.0 \mathrm{~m}\right)$ に留まるように設計 している.ここで, 取鍋の水平方向搬送における位置制御システムは, 比例制御による位置フィードバック制御 システムを構成している．

\section{5. 実 験 結 果}

本稿で提案する落下位置制御の有用性を検証するために，図 13 に示す落下位置制御システムを自動注湯機に実 装し，注湯実験を行う．注湯実験では，出湯口先端と鋳型湯口上面の垂直方向の距離を一定とし，注湯中に注湯流 量を変化させる実験を行う . また, 注湯流量を一定にして, 取鍋を垂直方向へ移動させることで, 出湯口先端と鋳 型湯口上面との垂直方向の距離を変動させた場合の実験も行う . 前者の実験条件のような注湯中の流量変化は, 実 際の鋳造現場でも湯口内液面レベルを一定にするために生じる現象である.一方で, 後者の実験条件で示す出湯口 先端と鋳型湯口上面との垂直方向の距離の変動は, 実際の鋳造現場ではあまり見られない . しかし, 本稿では落 下位置制御の性能を評価するために, 出湯口先端と鋳型湯口上面との垂直方向距離の変動を伴う注湯実験も行う .

\section{$5 \cdot 1$ 注湯流量を変化させた注湯実験}

本注湯実験では, 鋳型内湯口上面と出湯口先端との垂直方向距離を $s_{w}=0.20 \mathrm{~m}$ 一定として, 注湯流量を $0.30 \times 10^{-3} \mathrm{~m}^{3} / \mathrm{s}$ から $0.55 \times 10^{-3} \mathrm{~m}^{3} / \mathrm{s}$ 一変化させる. $3.50 \mathrm{~s}$ から $5.00 \mathrm{~s}$ の間を定常流量 $0.30 \times 10^{-3} \mathrm{~m}^{3} / \mathrm{s}$ とし， $8.00 \mathrm{~s}$ か ら $9.50 \mathrm{~s}$ 間を定常流量 $0.55 \times 10^{-3} \mathrm{~m}^{3} / \mathrm{s}$ としている.この実験条件における注湯実験の結果を図 14 に示す.

図 14(a) は目標注湯流量であり，(b) は注湯プロセスの逆モデルによる流量制御によって得られた傾動用モータ への指令電圧である . (c) は取鍋の傾動角度であり，(d) はロードセルによって計測された流出液体重量である . (e) は図 13 に示すブロック $E_{f}$ から推定された出湯口での平均流速であり, (f) はブロック $E_{o}$ から推定された流出液 

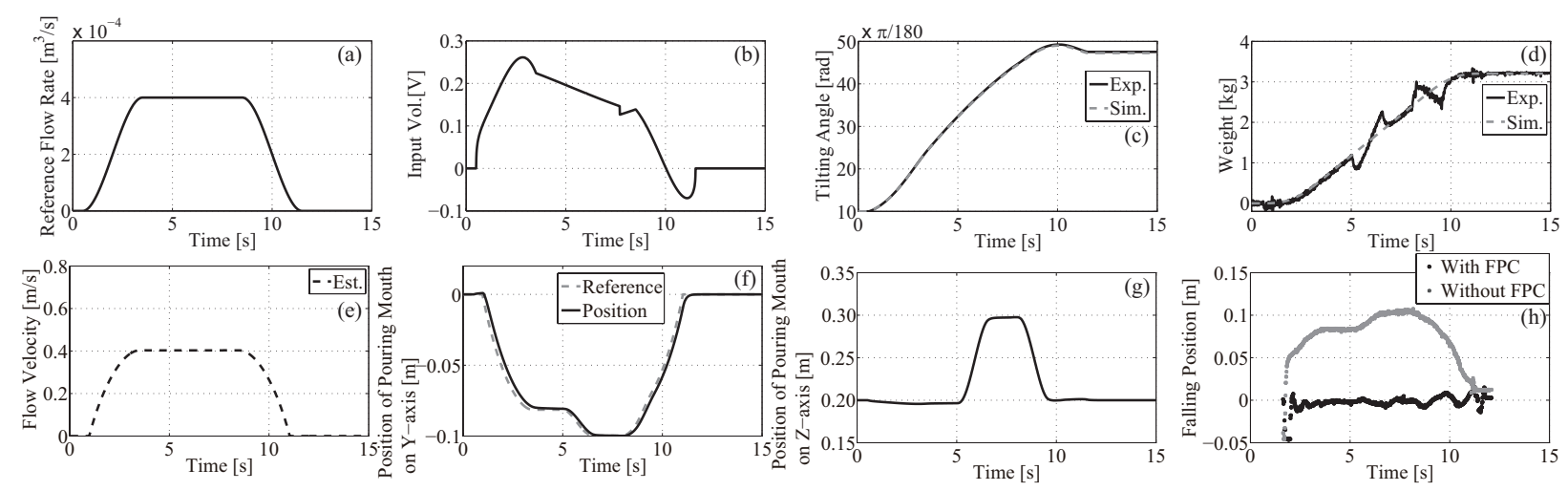

Fig. 15 Experimental Results with Transferring Ladle on Z-axis

体の落下位置に基づいて水平方向へ搬送される取鍋出湯口の水平方向移動距離である（g) は鋳型内湯口上面を原 点とした出湯口先端の垂直方向の位置である . (h) は鋳型内湯口中心を原点とした流出液体の水平方向の落下位置 である．図14(c)(d)において，実線は実験結果であり，破線はシミュレーション結果である．図 14(e) では, 出湯 口先端における平均流速の推定值を破線で示す．また，図14(f) における破線は，取鍋水平搬送のための位置制御 システムへ与えられる目標軌道であり，実線が出湯口先端の水平方向位置である . 図 14(h) では, 黑丸か落下位置 制御による流出液体の落下位置であり, 薄色の+印は比較対象として, 従来の注湯制御手法 (落下位置制御は用い ずに，出湯口先端を定点化）による流出液体の落下位置を示す. 図 14(h) に示されるように, 出湯口先端を定点化 させた従来手法では, 注湯流量の増加に伴って, 流出液体の落下位置と目標位置との誤差が増加しており, 所望の 落下位置との誤差が最大で $0.102 \mathrm{~m}$ に達している.一方で, 本稿で提案した落下位置制御を用いることで, 注湯流 量が変動しても所望の落下位置である湯口中心 $\left(s_{y}=0.0 \mathrm{~m}\right)$ に対して, $0.016 \mathrm{~m}$ 以内に液体を注湯していることが確 認された .ここで, 注湯開始直後 ( $1.9 \mathrm{~s}$ 付近) において, 落下位置制御の有無に関わらず, 落下位置が $-0.025 \mathrm{~m}$ と なっている．これは, 注湯初期の流出液体の流速が低速のため, 取鍋表面と水との濡れ性の影響により液体が取 鍋外側表面を伝って, 落下したことによる. 本研究では, 取鍋表面と液体の界面の影響を考慮していないが, 図 14(h) からもわかるように, 落下位置制御を用いた際の注湯初期を除いた流出液体は, 所望の落下位置近傍に注が れており，注湯中の流速ではこの影響は微小と考える .

\section{$5 \cdot 2$ 取鍋を上下方向へ移動させた場合の注湯実験}

本実験では，定常流量を $0.40 \times 10^{-3} \mathrm{~m}^{3} / \mathrm{s}$ 一定として，取鍋を垂直方向へ移動させた注湯実験を行う．この実験 において，鋳型内湯口上面から出湯口先端までの垂直距離が， $6.50 \mathrm{~s}$ から $8.00 \mathrm{~s}$ の間に $0.20 \mathrm{~m}$ から $0.30 \mathrm{~m}$ となる. この実験条件における注湯実験の結果を図 15 に示す. 図 15 において，図の配置および線種は図 14 と同樣である. 図 15(d) に示す流出液体重量において, 5s から 10s の実験結果はシミュレーション結果と比較して, 変動してい ることが確認できる .これは, 取鍋を上昇させた際の取鍋重心の移動によって, ロードセルの重量データが変動 したことによるものであり, 液体の流出重量の変動ではない．したがって，5s から $10 \mathrm{~s}$ の結果の除くシミュレー ション結果と実験結果を比較すると，シミュレーション結果が実験結果に精度良く追従している．このことから， 自動注湯機の数理モデルが, 実際の注湯プロセスを精度良く表現していることか確認できる. 図 $15(\mathrm{~g})$ に示す鋳型 内湯口上面から出湯口先端までの垂直距離が $0.20 \mathrm{~m}$ から $0.30 \mathrm{~m}$ へと移動していることが確認できる. 弚れに伴っ て, 図 15(f)に示すように, 落下位置制御により流出液体の落下位置が推定され, 出湯口先端の水平方向位置が後 方へ移動している. 図 15(h) では, 落下位置制御を用いない場合, 流出液体の落下位置と目標位置との誤差が, 取 鍋の上昇に伴って増加しており，所望の落下位置との誤差が最大で $0.104 \mathrm{~m}$ に達している，一方で，落下位置制御 を用いることで, 取鍋が垂直方向へ移動した場合においても，所望の落下位置（湯口中心）に対して，注湯開始 直後を除いて $0.015 \mathrm{~m}$ 以内に液体が落下しており，高精度に所望の落下位置へ注がれていることか確認された．

本研究では, フィードフォワード型落下位置制御を提案し, 外乱が無い環境下において高精度に所望の位置へ注 湯できることを示した．しかし，注湯工程では取鍋にノロが付着するなどの外乱が生じることが想定される .こ のような場合は, 本研究で提案しているフィードフォワード型落下位置制御に加え, カメラなどにより落下位置 
を実時間計測し，落下位置誤差をフィードバック補償する 2 自由度型落下位置制御などの構築が必要となる．

$$
\text { 6. おわりに }
$$

本稿では, 鋳造業における取鍋傾動式自動注湯機に対して, 所望の位置へ取鍋から流出する液体を高精度に注 湯する流出液体の落下位置制御を提案した . また , 流出液体の落下位置を計測するためのカメラシステムを備え た取鍋傾動式自動注湯機に本稿で提案した落下位置制御を実装し、弚の有用性を実験検証した . 本研究で得られ た成果を次に示す.

1. 取鍋傾動式自動注湯機における注湯プロセスの数理モデルを拡張し，モータへの指令電圧から流出液体の落 下軌跡までの注湯プロセスを数理モデルで表現した .

2. 出湯口先端における流出液体の断面収縮を考慮した平均流速を導出し, 弚の平均流速に基づいて, 大気中に 放出された流出液体を放物運動でモデル化することで, 落下軌跡を精度良く表現できることを示した．

3. 注湯プロセスの数理モデルにより推定された流出液体の落下位置に応じて, 取鍋の水平方向位置を制御する ことで所望の位置へ流出液体を注湯させるフィードフォワード型落下位置制御を提案した .

4. 取鍋傾動式自動注湯機を用いた実験検証により，本稿で提案する落下位置制御を自動注湯機へ実装すること で, 所望の位置に高精度に注湯できることが確認された。

本稿では，対象液体を水として実験を行ったが，実際の鋳造現場で用いられる溶湯に対しても本稿で提案して いる落下位置制御系設計法における, 注湯プロセスモデルの流量係数および出湯口先端での液体断面収縮を考慮 した平均流速を求める際の補正パラメータを同定することで, 流出溶湯の落下位置の高精度化が実現できるもの と考える。

文献

(1) Lindsay, W., “Automatic Pouring and Metal Distribution Systems”, Foundry Trade Journal, Vol. 10, (1983), pp.151-176.

(2) Thielk, J., "Using Electric Furnances to Store and Pour Treated Ductile Iron Part 2", Modern Casting, (1987), p. 25.

（3）寺嶋一彦，“鋳造業における自動注湯・溶湯搬送の現状”, 素形材, Vol. 39, No. 6, (1998), pp. 1-8 .

(4) Kozuszek, K., “Robotic Problem Solving”, Modern Casting, (2006), p. 24.

(5) 西田理, “注湯工程の自動化”, 素形材 , Vol. 47 , No. 10 , (2006), pp. 6-10.

（6）野田善之，西田理，“取鍋傾動式自動注湯機による鋳込重量の精度解析”, 鋳造工学，Vol. 81, No. 9，(2009)，pp. 451-456.

(7) Neumann, E., Trauzeddel, D., "Pouring Systems for Ferrous Applications”, Foundry Trade Journal, Vol. 23, (2002), pp. 23-24.

（8）野田善之, 寺嶋一彦, “高速・高精度自動注湯ロボットにおける制御システム”, 精密工学会誌, Vol. 76, No. 4, (2010) , pp. 390-394.

（9）松田政夫 ,頃安貞利 , “自動注湯機の傾動軸 2 段昇降装置による初期流量増大化の試み”, 鋳造工学, Vol.71, (1999), pp.437-442.

(10) 頃安貞利，松田政夫，“傾動軸昇降自動注湯機による湯口系流れに関する研究”，日本機械学会関東支部ブロック講演会講 演論文集 , (2000), pp. 39-40.

（11）篠原一寛，森本博幸，“自動注湯機の開発”, 自動車技術，Vol. 46，No. 11，(1992), pp. 79-85.

(12) 矢野賢一, 金子元樹, 杉本祐, 寺嶋一彦, “注湯プロセスにおける熟練技能を実現する自動注湯ロボットのスーパーバイ ザリ制御”, 日本ロボット学会誌, Vol. 21 , No. 6, (2003), pp. 90-101.

(13) 矢野賢一, 杉本祐, 野田善之, 寺嶋一彦, “Betterment Processによる円筒取鍋型自動注湯ロボットの注湯流量制御”, 日 本機械学会論文集 C 編, Vol. 70 , No. 694, , (2004), pp. 206-213.

(14) 栗山嘉文, 林脩一朗, 矢野賢一, 渡邊守, 西戶誠志, “CFD 最適化問題のための極值近傍探索アルゴリズムの構築とダイ カストプロセスへの適用”, 鋳造工学, Vol. 83 , No. 5 , (2011), pp.253-258.

(15) Y. Kuriyama , K. Yano , S. Nishido , "Optimization of Pouring Velocity for Aluminium Gravity Casting” , Fluid Dynamics, Computational Modeling and Applications , Chapter 6 , (2012), InTech. 
(16) 野田善之, 寺嶋一彦, “傾動式自動注湯システムにおける注湯流量モデルと逆モデルによる注湯流量フィードフォワード 制御”，日本機械学会論文集 C編，Vol. 72，No. 722，(2006)，pp.3147-3154.

(17) Noda, Y. , Terashima, K. , "Modeling and Feedforward Flow Rate Control of Automatic Pouring System with Real Ladle" , Jornal of Robotics and Mechatronics , Vol. 19 , No. 2 , (2007) , pp.205-211.

（18）野田善之，寺嶋一彦，鈴木薪雄，橋本邦弘，“高精度自動注湯ロボットを実現する流出重量シーケンス制御”, 計測自動制 御学会産業論文集，Vol.9，No.14，(2010)，pp. 98-107.

(19) 橋本邦弘 , “わが社の環境調和型ものづくりへの貢献 - 鋳造設備による CO2 削減事例の紹介 - ”, 素形材, Vol. 52 , No. 5 , (2011), pp. 2-7.

(20) 矢野賢一, 寺嶋一彦, 川岸博伸, “CFD によるスロッシング解析と溶湯搬送制御システム設計”, 日本機械学会論文集 C 編 , Vol. 68 , No. 671 , (2002), pp. 2001-2008.

(21) 末松良一，山田宏尚，画像処理工学，5.4 章，(2000)，コロナ社.

(22) Terashima, K., Yano, K. ,"Sloshing-suppression Control of Tilting-type Automatic Pouring Machine” , Proceedings of 14th IFAC World Congress, No.1 , (1999), pp. 25-30.

(23) Noda, Y., Terashima, K. , "Falling Position Control of Outflow Liquid for Automatic Pouring System with Tilting-type Ladle" , Proceedings of 12th IFAC Symposium on Automation in Mining, Mineral and Metal Processing, (2007), pp. 53-58.

(24) 前田昌信, 流体力学, (2002), pp.46-48, オーム社.

（25）林泰造，基礎水理学，(1996), pp.98-119，鹿島出版会. 